\title{
Interbular Space Characterization in Adult Capybara (Hydrochoerus hydrochaeris) Testis
}

\author{
Tarcízio Antônio Rego de Paula ${ }^{1}$, Sérgio Luiz Pinto da Matta ${ }^{2}$, Valdemiro Amaro da Silva \\ Jr. $^{3}$, Deiler Sampaio Costa ${ }^{4}$, Cláudio Cesar Fonseca ${ }^{1}$ and Marco Túlio David das Neves ${ }^{1}$ \\ ${ }^{1}$ Departamento de Veterinária; ${ }^{2}$ Departamento de Biologia Geral; Universidade Federal de Viçosa; \\ tarcizio@ufv.br; smatta@ufv.br; Viçosa - MG - Brasil. ${ }^{3}$ Departamento de Morfologia; Universidade Federal de \\ Pernambuco; Pernambuco - PE - Brasil. ${ }^{4}$ Departamento de Veterinária, Universidade Estadual Norte Fluminense; \\ Campos - RJ - Brasil
}

\begin{abstract}
This study aimed at the qualitative and quantitative characterization of the different intertubular tissue components in adult male capybara. Testes of 15 adult capybaras from a commercial slaughterhouse of wild animals were used. The average percentage of Leydig cells was $32.95 \pm 10.03 \%$, whereas in the other components of the intertubular space it was $14.95 \pm 4.79 \%$, thus the whole intertubular space totalized $47.91 \pm 11.48 \%$. The average weight of the testes were $32.83 \pm 4.78 \mathrm{~g}$, while the animals' body weight were around $52.37 \mathrm{~kg}$ and the gonadosomatic and leydigosomatic indexes were $0.125 \pm 0.02 \%$ and $0.0411 \pm 0.0148 \%$ respectively. It was concluded that the leydigosomatic index of the capybaras was lower than the one observed in rats, as well as the arrangement of the components in intertubular tissue was similar to pattern I of Fawcett's classification as was found in guinea-pigs and chinchillas.
\end{abstract}

Key words: Intertubular space · Leydig cell · testis ' capybara · Hydrochoerus hydrochaeris

\section{INTRODUCTION}

The endocrine portion in mammals' testicles is represented by the Leydig cells that together with conjunctive cells, leukocytes, blood and lymphatic vessels form the intertubular space or intertubular tissue. Testosterone is the main product from mature Leydig cells, and the arrangement and proportion of all components of the intertubular space vary among the different mammal species and form mechanisms that maintain the level of testosterone two to three times higher in the interstitial fluid than in the testis blood vessels, as well as 40 to 250 times higher in these vessels relative to the peripheral blood (Sharpe, 1994).
Until now, the highest proportion of intertubular tissue among mammals was registered for the adult male capybara; in this animal, the intertubular tissue reaches proportions above 50\% of the testicular parenchyma (Moreira et al., 1997a; Paula, 1999).

Capybaras are the biggest alive rodents, and males can reach up to $80 \mathrm{~kg}$ of body weight. They present a strong social hierarchy by living in family groups headed by a dominant male that usually round up 6 to 8 females and several younglets. Other adult males are not admitted into the group, and are kept at periphery through strong aggressive interactions from the dominant male. They are very territorialist animals, and the

\footnotetext{
${ }^{*}$ Author for correspondence
} 
dominant male is the main animal implied in demarcation of the occupied territory, and it performs this activity by using an exclusive odoriferous gland in his face called the nasal gland. The significant correlation between this gland volume and daily spermatic production per testes shows that this gland could be used as a reliable reference in determination of the hierarchical position of the dominant animals (Paula, 1999). Due to these behaviors, as well as the abundance of the intertubular tissue and the low sperm production, it is plausible to infer that adult male capybaras usually invest more on androgenic production in detriment of sperm production (Moreira et al., 1997a).

According to Fawcett et al. (1973), generally the arrangement and the proportion of the elements constituting the intertubular space in the different mammalian species follow three different patterns: (I) species in which the Leydig cells and the conjunctive tissue occupy a very small area in the intertubular compartment, so contrasting to the extensive lymphatic sinusoids or lymphatic spaces; (II) species presenting groups of Leydig cells spread throughout abundant and edematous conjunctive tissue which is drained by a lymphatic vessel located either at the center or eccentrically in the intertubular space; and (III) species in which abundant groupings of Leydig cells practically occupy the whole intertubular compartment, presenting just a few of conjunctive and lymphatic tissues.

In general, the rodents present the type I pattern with some variation related to the continuity of the coating epithelium in lymphatic spaces (Clark, 1976; Russell, 1996). In relation to the proportion of Leydig cells, no other rodent approaches the pattern observed in capybara. Thus, the objective of this study was to qualitative and quantitatively characterize the different components of the intertubular tissue of the adult male capybaras, through light microscopy and transmission electronic microscopy.

\section{MATERIALS AND METHODS}

Testes of 15 adult capybaras (Hydrochoerus hydrochaeris), from commercial slaughterhouse in Iguape county, São Paulo State -Brazil were used. The animals came from private producers regularly authorized by the Instituto Brasileiro de Recursos Naturais Renováveis (IBAMA) located in São Paulo State. After slaughter, the animals were weighed, and their testis and respective epididymis were collected. Randomly, one of the testes was dissected in order to observe the percentile occupied by albuginea and mediastinum testis, while the testicular artery of the counterlateral testis was cannulated nearly the extremity capitata. Next, the testis was perfused at the room temperature with $0.9 \%$ saline solution containing heparin (125 UI/liter) for 5 minutes. Fixation was then accomplished with $3 \%$ glutaraldehyde solution in $0.1 \mathrm{M}$ cacodylate buffer at $\mathrm{pH} 7.4$ at room temperature for approximately 20 minutes. After perfusion, each testis was weighed after being separated from the respective epididymis. The perfused testis was sectioned and some fragments of its medium third were refixed by immersion into $5 \%$ glutaraldehyde solution for two hours. For analysis under light microscope, fragments were dehydrated at increasing concentrations of alcohols, embedded in plastic resin of the glycol methacrilate type, sectioned at $4 \mu$-thickness sections and stained in toluidine blue solution - $1 \%$ sodium borate.

Testis fragments from six animals were analyzed by electron transmission microscopy. After immersion into 5\% glutaraldehyde, they were post-fixed for one hour in solution of $1 \%$ osmium tetroxide plus $1.5 \%$ potassium ironcyanide in cacodylate buffer. After dehydration, the fragments were embedded in resin Epon. Ultrathin $30 \mathrm{~nm}$ - thick sections were transferred to 100 -mesh copper screens and contrasted with $5 \%$ acetate uranile and $1 \%$ lead citrate. The proportion of the different testicular parenchyma components were quantified by light microscopy, through an integrating ocular provided with 400 points that were computed in 20 fields randomly distributed in each animal. The arrangement of the different components in the intertubular tissue was characterized in micrographs of varying magnitude under electronic microscope.

All data were analyzed by the software Excel for Windows (Version 7, 2001). In addition to correlation analyses, results were expressed as means and standard errors.

\section{RESULTS AND DISCUSSION}

In functional terms, the mammalian testes may be divided into two basic compartments: the tubular or spermatogenic compartment and the 
intertubular or androgenic compartment. The proportion between these compartments is quite variable, and constitutes one of the main factors responsible for the differenciated efficiency in sperm production observed in several species (Russell et al. 1990b; França and Russell, 1998). In adult male capybaras, the intertubular space embraced about $50 \%$ volume of the testicular parenchyma (Table 1), so contrasting with about the $72 \%$ found by Moreira et al. (1997b).

It appeared that philogenetic factors werenot responsible for determination of the percentile occupied by the intertubular compartment in different mammal species. Thus, among the studied rodents, enormous variation was observed in the different species, even when the same gender was considered (Fawcett et al., 1973; Breed, 1982). In domestic mammals, the percentile occupied by the intertubular space could vary from $10 \%$ in the dog to $40 \%$ in the camel (França and Russell, 1998).

During the testicle development, or more precisely at puberty, and during the testicular recrudescence in seasonal animals, the Sertoli cell that is the main regulator of the spermatogenic process, becomes no more modulated by the follicle stimulating hormone (FSH) which is gradually substituted by testosterone (Means et al., 1976; Jégou et al., 1982; Sharpe, 1994).Therefore, as a preparation for this substitution, the Leydig cells should be numerical and physiologically adapted to give support to the new requirement of testosterone. The FSH seems to directly influence on development of this population (Sharpe, 1994). Peritubular mesenchymal cells are the precursors to Leydig cells at the onset of Leydig cell differentiation, the onset of precursor cell differentiation into progenitor cells is independent of LH. However, $\mathrm{LH}$ is essential for the later stages in the Leydig cell lineage to induce cell proliferation, hypertrophy, and establish the full organelle complement required for the steroidogenic function (Mendis-Handagama and Ariyaratne, 2001).

In a wide range of the mammals the main element constituting the intertubular compartment is the Leydig cells. In capybara under study, practically $1 / 3$ of the testicle was occupied by Leydig cells. An individual variation from 13 to $51.7 \%$ was observed (Table 1). Working with 72 animals for two years, Paula (1999) demonstrated that there was no qualitative or quantitative sazonal variation between elements of capybara testis. The amount of Leydig cells was quite variable among the several species of mammals, and this variation wasnot found for other endocrine glands (Fawcett et al., 1973). The other components of the intertubular space, however, presented less evident variations in the different species. For example, the intertubular conective tissue corresponded to approximately $7 \%$ of the testicular parenchyma in Piau swine (França, 1991), 7.5\% in dog (Paula and Cardoso, 1994) and $8 \%$ in capybara. The lymphatic space practically occupy the same percentile of the testicular parenchyma (about $3.5 \%$ ) in capybara (Paula, 1999) and rat (Russell and França, 1995).

In addition to the already well-known endocrine control through the hypothalamus- hypophysistesticle axis, an elaborated system of intercellular communication is developed in the testicle to assure the perfect functioning of the spermatogenic process (Roser, 2000). Thus, the cells directly or indirectly involved in the production of the male gametes, that is, Sertoli cells, germ cells, Leydig cells, peritubular mioid cells, leukocytes, etc, maintain a paracrinous/autocrine system that modulates this intricate net of cellular interaction, which is fundamental for the perfect functioning of the testicle (Schlatt, 1997; Zirkin and Chen, 2000; Rothschild et al., 2003). The contribution of the Leydig cell for this paracrine communication involves the production of different substances (Lejeune et al., 1997; Roser, 2000; França et al., 2000). In vitro studies correlating the structure and function of the Leydig cells in several mammal species showed that the variations in testosterone secretion resulted more from the individual ability of this cell in secreting testosterone than from differences in the total volume of these cells (Ewing et al., 1979). This ability is highly associated to the amount of the smooth endoplasmic reticulum present in the Leydig cell (Zirkin et al., 1980). 
Table 1 - Volumetric proportion (\%) of the intertubular space components, body and testicle weights, gonadosomatic and Leydigosomatic indices in adult capybara

\begin{tabular}{|c|c|c|c|c|c|c|c|}
\hline Animal & $\begin{array}{c}\text { Leydig cells } \\
(\%)\end{array}$ & $\begin{array}{c}\text { Other } \\
\text { components/ } \\
\text { intertubular } \\
\text { space }(\%)\end{array}$ & $\begin{array}{c}\text { Total } \\
\text { Intertubula } \\
\text { r space }(\%)\end{array}$ & $\begin{array}{c}\text { Testicle } \\
\text { weight* } \\
\text { (g) }\end{array}$ & $\begin{array}{c}\text { Body } \\
\text { weight } \\
\text { (kg) }\end{array}$ & $\begin{array}{l}\text { Gonadosomatic } \\
\text { index }(\%)\end{array}$ & $\begin{array}{c}\text { Leydigosomatic } \\
\text { index }(\%)\end{array}$ \\
\hline 01 & 46,6 & 19,6 & 66,2 & 27,5 & 52 & 0,105 & 0,0489 \\
\hline 02 & 51,7 & 13,9 & 65,6 & 42,9 & 53 & 0,162 & 0,0837 \\
\hline 03 & 38,5 & 16 & 54,5 & 40,2 & 61 & 0,131 & 0,0504 \\
\hline 04 & 28,2 & 14,2 & 42,4 & 26,6 & 47 & 0,113 & 0,0318 \\
\hline 05 & 31,5 & 14,1 & 45,6 & 31,0 & 52 & 0,119 & 0,0374 \\
\hline 06 & 13,4 & 7,5 & 20,9 & 33,1 & 48 & 0,138 & 0,0184 \\
\hline 07 & 26 & 20,2 & 46,2 & 32,7 & 51 & 0,128 & 0,0332 \\
\hline 08 & 35,8 & 13,6 & 49,4 & 30,4 & 54,5 & 0,111 & 0,0397 \\
\hline 09 & 30,6 & 7,4 & 38,0 & 31,1 & 53,5 & 0,116 & 0,0354 \\
\hline 10 & 45 & 9,2 & 54,2 & 28,6 & 54 & 0,106 & 0,0477 \\
\hline 11 & 30,1 & 21,7 & 51,8 & 37,3 & 62 & 0,120 & 0,0361 \\
\hline 12 & 27,3 & 23,3 & 50,6 & 30,9 & 43,5 & 0,142 & 0,0387 \\
\hline 13 & 35,1 & 13,4 & 48,5 & 28,1 & 51 & 0,110 & 0,0386 \\
\hline 14 & 19,6 & 13,8 & 33,4 & 35,4 & 53 & 0,133 & 0,0260 \\
\hline 15 & 34,9 & 16,4 & 51,3 & 36,6 & 50 & 0,146 & 0,0509 \\
\hline Average $\pm \mathrm{se}^{* *}$ & $32,95 \pm 10,0$ & $14,95 \pm 4,8$ & $47,91 \pm 11,5$ & $32,83 \pm 4,8$ & $52,37 \pm 4,7$ & $0,125 \pm 0,02$ & $0,0411 \pm 0,015$ \\
\hline
\end{tabular}

The well-known high production of testosterone does not justify the wide variation observed for the percentile occupied by Leydig cells in testicle. An adequate concentration of testosterone in blood is necessary to maintain male sexual secondary characteristics. Hence, it is expected that the bigger the animal, the more testosterone will be necessary. However, the requirement for sperm production is more or less constant for each species or, at least, it is

not so dependent on the animal size (Russell, 1996). Therefore, the proportional variation of the Leydig cells in testicle might be more related to the body size than to spermatic production (Paula, 1999). According to Fawcett et al. (1973) and Russell (1996), the largest amount of the Leydig cells in some species may be related to the synthesis of other steroid types, such as pheromones or substances with some other functions still indefinite. Considering the other steroid types produced by

Leydig cells, investigations have shown that estrogen is very important in the functional control of a portion of the spermatic ducts (Hess et al., 1997). In equine, such as in capybaras, that present high proportions of Leydig cells in testicle, high amounts of estrogen are produced (Raeside, 1969), supporting the concept that in equine estrogen assumes an important role in libido and sperm production.

Several other factors can influence the amount of Leydig cells per animal, which include: the amount of available $\mathrm{LH}$; the number of $\mathrm{LH}$ receptors per cell; the amount of testosterone that Leydig cell is able to secrete at a given time; the speed the testosterone leaves the testicle through lymphatic vessels, blood vessels and seminal fluid; the animal's blood volume and the testosterone metabolism rate (Russell et al., 1994; Russel, 1996). In this sense, observing that $2.2 \%$ of the rat testicles were occupied with Leydig cells (MendisHandagama, et al., 1988), this value was lower than $33 \%$ observed in capybara testicles (Table 1). However, if were these values the percentile of the body weight allocated into testicle (gonadosomatic index) for rat $4.26 \%$ (Kenagy and Troumbulak, 1986) and for capybara $0.125 \%$ (Table 1), the body weight index allocated into the Leydig cell (leydigosomatic index) for rat was of $0.094 \%$ and for capybara $0.041 \%$ (Table 1). Thus, proportionally the rat actually presented about twice the amount of Leydig cells than those 
observed in capybaras. Thus, the volumetric testicle proportion seemed to reflect not the real physiologic requirement of the Leydig cells per animal.

The models described by Fawcett et al. (1973) for arrangement of the intertubular space components indicated a wide variation relative to the amount of the Leydig cells as well as the disposition of the lymphatic vessels/ spaces. Although there was little knowledge regarding the physiologic implications of this variation, Fawcett et al. (1973) speculated that this variation was probably related to the ability of the lymphatic vessels in moving out the testis the materials vascularly secreted and to maintain the appropriate androgen concentrations in both the testicle and blood vessels. Capybara's testis consisted of abundant intertubular space with clusters of Leydig cells and extensive lymphatic sinusoids or lymphatic spaces (Fig. 1).

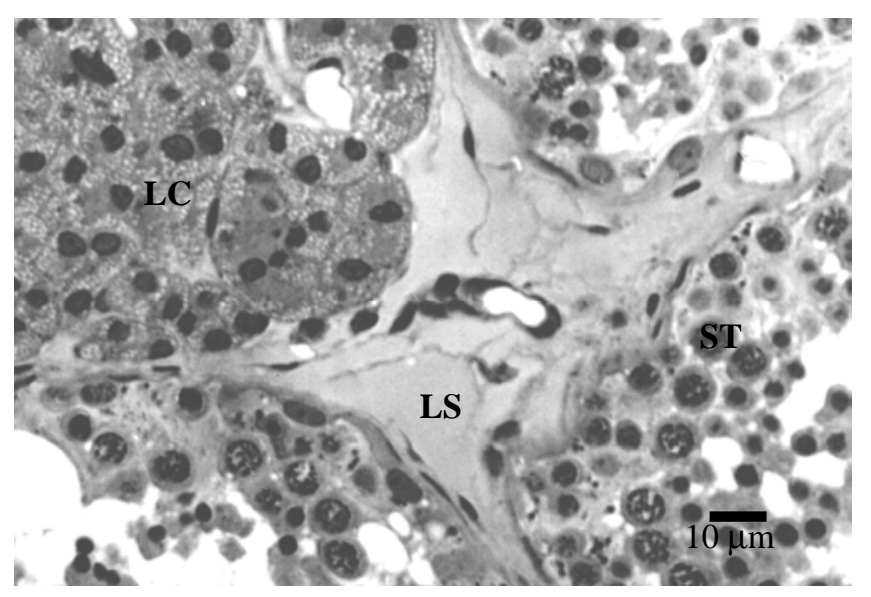

Figure 1 - Light micrography of capybara's testis showing the lymphatic space (LS), Seminiferous tubule (ST) and cluster of Leydig cells (LC) .

In general, the rodents present the pattern of the type I described by Fawcett et al. (1973), in which a small amount of Leydig cells and the blood vessels are separated from the seminiferous tubules by a very developed lymphatic space (Fig. 2). This lymphatic space is covered with a visceral endothelium layer which involves the Leydig cells and the blood vessels, as well as by the parietal layer contacted with the tunica propria of the seminiferous tubules (Fig. 3). From more detailed studies showing that only in rat, hamster and mouse the visceral endothelium is discontinuous in areas where three seminiferous tubules meet (Clark, 1976; Russell, 1996), leaving the Leydig cells in direct contact with the lymph in these areas, so one subdivision of the architectural pattern of the type I was added. (Fig. 2a).

Considering the disposition and high volumetric proportion of the Leydig cells in capybara, this species should be included into pattern of the type III of Fawcett's classification, according to Moreira et al. (1997). However, the arrangement and disposition of the lymphatic space in this species is similar to those observed in guinea-pigs and chinchilla (Fig. 2b), where the lymphatic visceral endothelium layer is continuous, making possible the inclusion of capybara into one more variation of the classification type I (Figs. 2c and 3). Although the reason why the organization of the lymphatic vessels/spaces presents variation in several mammal species is yet unknown, it seems logical to suppose that the phylogeny plays an important role in determination of their architectural arrangement, since capybara the guinea-pigs and chinchilla pertain to the same evolutionary branch within suborder Hystricognathi (Thenius et al., 1975). 

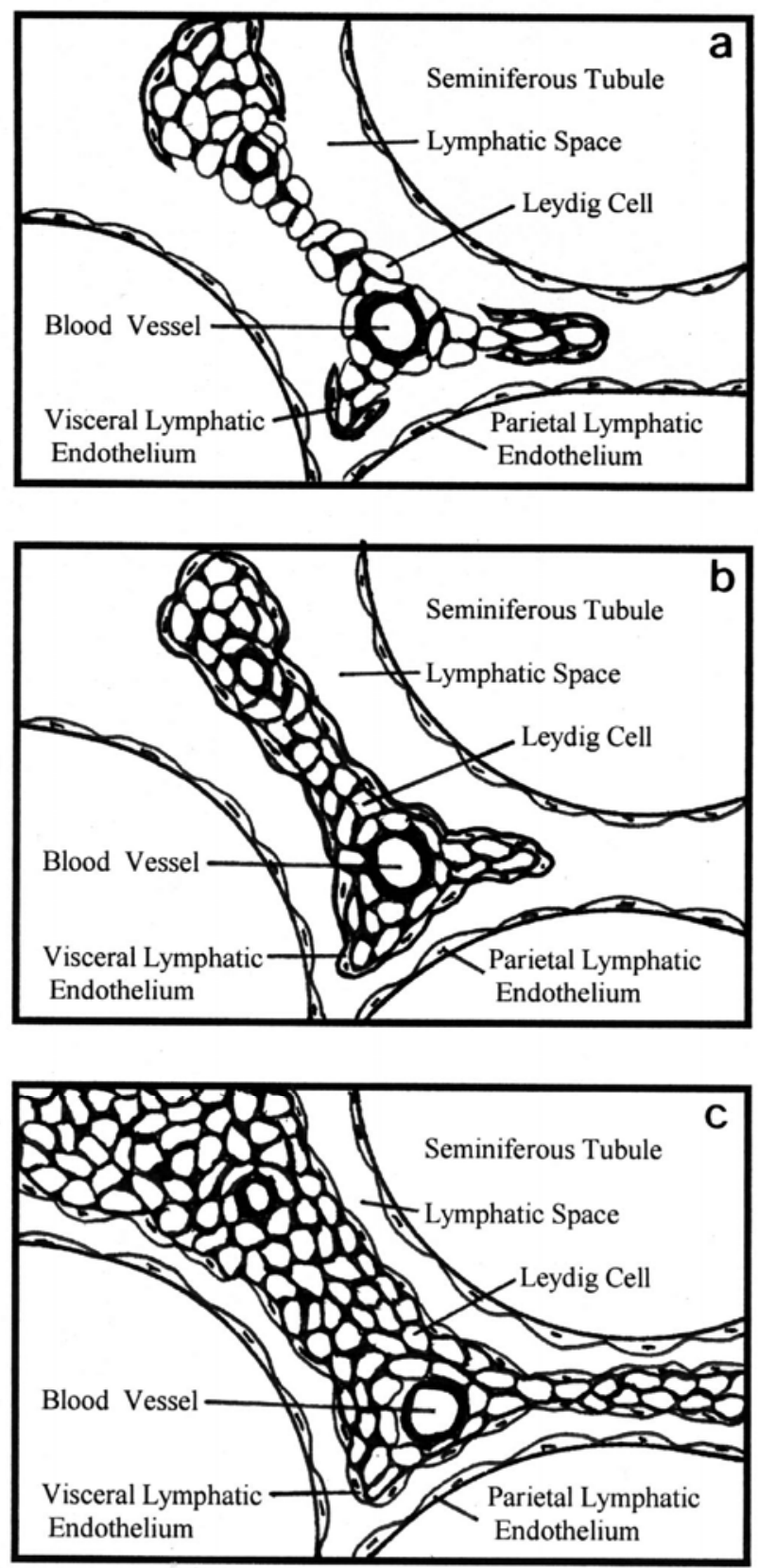

Figure 2 - Intertubular space type I pattern of the rat (Clark, 1976), mouse and hamster (Russel, 1996)(a), guinea pig and chinchilla (Russel, 1996)(b) and capybara (present study) (c). 


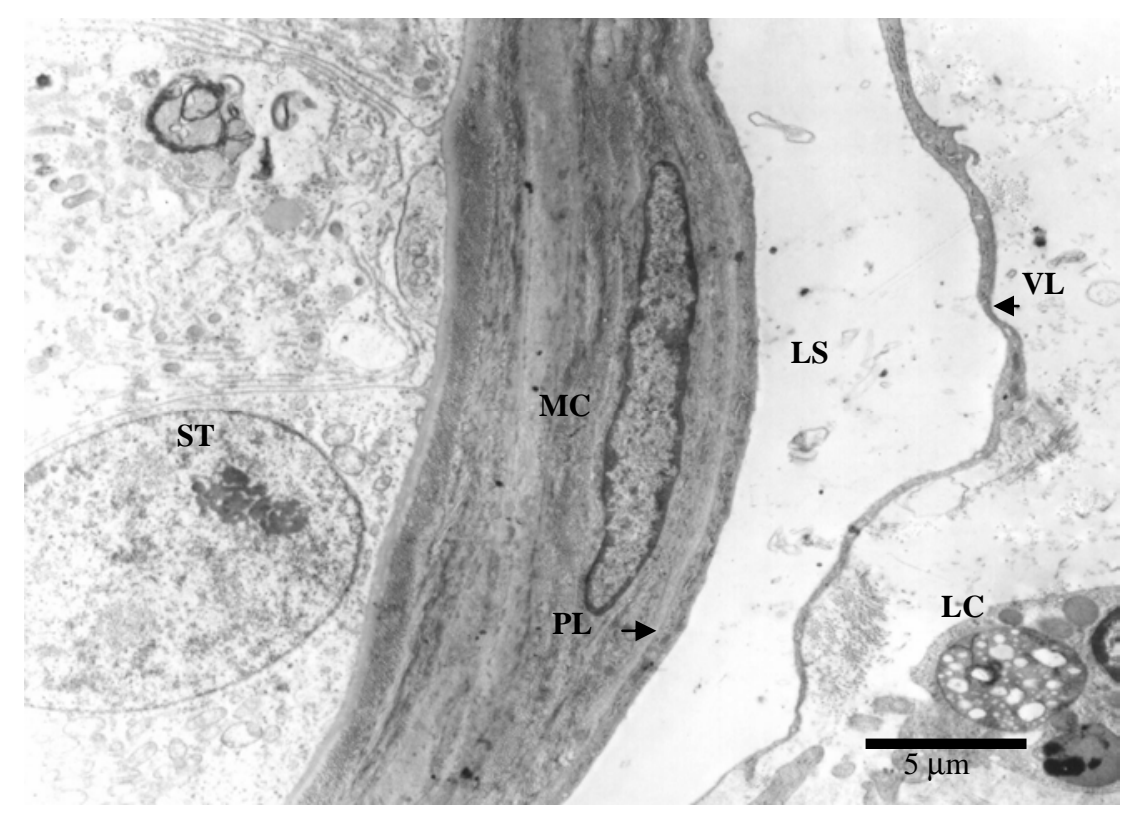

Figure 3 - Transmission electron micrography of capybara's testis showing the lymphatic space (LS) underlying by parietal (PL) and visceral (VL) endotelial layers. Seminiferous tubule (ST), Myoid cell (MC) and Leydig cell (LC) are show at boundaries of lymphatic space

\section{CONCLUSIONS}

By observation of the data referring to the volumetric proportion of the testicular parenchyma components and the gonadosomatic index, one may conclude that although capybara presents one of the highest volumetric proportions of Leydig cells already registered for a mammal, the proportion of body weight allocated in the Leydig cells (Leydigosomatic index) is lower than that observed in rats. Thus, it may be inferred that the volumetric testicular proportion does not reflect the real physiologic requirement of these cells.

In relation to arrangements of the intertubular tissue components, in capybara the distribution is similar to that observed in type I Fawcett's classification to guinea-pigs and chinchillas, except for the amount of Leydig cells, making possible the inclusion of capybara into one more variation of the type I classification.

\section{ACKNOWLEDGEMENTS}

This study received financial support from CAPES (Brasília), Brazil.

\section{RESUMO}

Objetivou-se com esta pesquisa caracterizar qualitativamente e quantitativamente os diferentes componentes do tecido intertubular de capivaras machos adultas. Utilizou-se testículos de 15 capivaras adultas, provenientes de um abatedouro comercial de animais silvestres. Encontrou-se um percentual médio de células de Leydig de $32,95 \pm 10,03 \%$, dos demais componentes do espaço intertubular de $14,95 \pm 4,79 \%$ e um total de espaço intertubular de $47,91 \pm 11,48 \%$. O peso médio dos testículos foi de $32,83 \pm 4,78 \mathrm{~g}$, o peso corporal dos animais foi em torno de $52,37 \mathrm{~kg}$ e os índices gonadossomático e leydigossomático foram, respectivamente, $0,125 \pm 0,02 \%$ e $0,0411 \pm 0,0148 \%$. Concluiu-se que o índice leydigossomático das capivaras é menor que o observado em ratos e que o arranjo dos componentes do tecido intertubular é semelhante ao descrito como padrão tipo I da classificação de Fawcett, similar ao encontrado em cobaios e chinchilas. 


\section{REFERENCES}

Breed, W. G. (1982) Morphological variation in the testes and accessory sex organs of australian rodents in the genera Pesudomys and Notomys. J. Reprd. Fert. 66 (2), 607-613

Clark, R. C. (1976) Three-dimensional organization of testicular interstitial tissue and lymphatic space in the rat. Anat. Rec. 184, 203-226

Ewing, L. L., B. R. Zirkin,, R. C. Cochran, N. Kromann,, C. Peters, N. Ruiz-Bravo (1979) Testosterone secretion by rat, rabbit, guinea pig, dog and hamster testes perfused in vitro, correlation with Leydig cell mass. Endocrinology. 105,(5), 1135-1142

Fawcett, D. W.; Neaves, W. B.; Flores, M. N. (1973). Comparative observation on intertubular lymphatics and the organization of the interstitial tissue of the mammalian testis. Biol. Reprod. 9, 500-532

França, L. R. (1991) Análise morfofuncional da espermatogênese de suínos adultos da raça Piau. Tese de Doutorado, Universidade Federal de Minas Gerais, Minas Gerais. 185p.

França, L. R.,;Russell L. D. (1998) The testis of domestic animals. In, Regadera, J. and MartinezGarcia (eds.). Male reproduction. A multidisciplinary overview. Churchill Livingstone, Madrid, pp. 197219

França, L.R.; Silva jr., V.A.; Chiarini-Garcia, H.; Garcia, S.K.; Debeljuk, L. (2000) Cell proliferation and Hormonal changes during postnatal development of the testis in the Pig. Biol. Reprod. 63, 1629-1636

Jegou, B., Le Gac, F., Kretser, D. M. (1982) Seminiferous tubule fluid and interstitial fluid production. I. Effects of age and hormonal regulation in immature rats. Biol Reprod. 27(3),590-595

Kenagy, G. J., Trombulak, S. C. (1986) Size and function of mammalian testes in relation to body size. J. Mammal. 67 (1), 1-22

Lejeune, H., F. Chuzel, P. Sanchez, P. Durand, J.P. Mather, J.M. Saez (1997) Stimulation of both recombinant inhibin $\mathrm{A}$ and activin $\mathrm{A}$ on immature Leydig cell function in vitro. Endocrinology 138, 4783-4791

Means, A. R., Fakunding, J. L., Huckins, C. Tindall, D. J., Vitale, R. (1976) Follicle-stimulating hormone, the Sertoli cell and spermatogenesis. Recent. Prog. Horm. Res. 32, 477-527

Mendis-Handagama, S.M.; Zirkin, B.R.; Ewing, L.L (1988) Comparision of components of the testis interstitium with testosterone secretion in hamster, rat, and guinea pig testes perfused in vitro. $A m \quad J$ Anat 181(1), 12-22

Mendis-Handagama, S.M.L.C; Ariyaratne, S. (2001) Differentiation of adult leydig cell population in the postnatal testis. Biol Reprod 65, 660-671
Moreira, J. R., Macdonald, D. W., Clarke, J. R. (1997a) Correlates of testis mass in capybaras (Hydrochoerus hydrochaeris), dominance assurance or sperm production? J Zool Lond 241, 457-463

Moreira, J. R., Clarke, J. R., Macdonald, D. W. (1997b) The testis of capybaras (Hydrochoerus hydrochaeris). J Mamm 78(4), 1096-1100

Paula, T. A. R. and Cardoso, F. M. (1994) Alterações etárias na espermatogênese do cão. I. Análise histométrica. Arq Bras Med Vet Zootec 46(1), 19-30

Paula, T. A., Chiarini-Garcia, H.; França, L. R. (1999). Seminiferous epithelium cycle and its duration in capybaras (Hydrochoerus hydrochaeris).Tissue Cell., 31(3),327-334

Raeside, J.I. (1969) The isolation of estrone sulphate and estradiol sulphate from the stallion testes. Can J Biochem. 47, 811-815

Roser, J.F. (2000) Reproductive endocrinology of the stallion. In, Samper, J.C. (Ed.), Equine Breeding Management and Artificial Insemination. Saunders Company, Philadelphia, pp 123-132

Rothschild, G.; Sottas, C.M.; Kissel, H.; Agosti, V.; Manova, K.; Hardy, M.P.; Besmer, P. (2003) A Role for kit receptor signaling in Leydig cell steroidogenesis. Biol Reprod 69.118-127

Russell, L.D., L.R. França,. (1995) Building a testis. Tiss. Cell. 27(2), 129-147

Russell, L. D., R. A. Ettlin, A. P. Sinha-Hikim, E. D. Clegg, (1990a) Histological and histopathological evaluation of the testis. Cache River Press, Clearwater, Florida

Russell, L. D., H. P. Ren, I. Sinha-Hikin, W. Schulze, A. P. Sinha-Hikin (1990b). A comparative study in twelve mammalian species of volume densities, volumes and numerical densities of selected testis components, emphasizing those related to the Sertoli cell. Am J Anat 188(1), 21-30

Russell, L. D., Chandrashekar, V., Bartke, A., SinhaHikim, A. P. 1994. The hamstes Sertoli cell in early testicular regression and early recrudescence, a stereological and endocrine study. Int J. Androl 17(2), 93-106

Russell, L. D. (1996). Mammalian Leydig cell structure. In, Payne, A. H., Hardy, M. P., Russell, L. D. (eds). The Leydig cell. Cache River Press. Vienna, IL, pp 286-289

Schlatt, S., Meinhardt, A. and Nieschlag, E., (1997). Paracrine regulation of cellular interactions in the testis, factors in search of a function. Eur. $J$. Endocrinol. 137, 107-117

Sharpe, R. M. (1994). Regulation of spermatogenesis. In. Knobil, E. and Neil, J. D. (eds) The phisiology of reproduction, 2ed. Raven Press, N.Y., pp.1363-1434

Thenius, E., Heinemann, D., Wendt, H., Mohr, E. (1975), The Cavies. In, Grzimek's animal life encyclopedia. eds. Van Nostrand Reinhold Company, New York, pp. 420-456 
Zirkin, B. R., Ewing, L. L., Kromann, N., Cochran, R. C. (1980). Testosterone secretion by rat, rabbit, guinea pig, dog, and hamster testes perfused in vitro, Correlation with Leydig cell ultrastructure. Received: March 01, 2005; evised: November 08, 2005; Endocrinology. 107, 1867-1874

Zirkin, B.R.; Chen, H. (2000) Regulation of leydig cell steroidogenic function during aging. Biol Reprod. 63,977-981 
PÁGINA

EM

BRANCO 